\title{
COSTING IN CONDITIONS OF CZECH HOSPITALS
}

\author{
Šárka Fialová $^{1}$ \\ ${ }^{1}$ Univerzita Tomáše Bati ve Zlíně, Fakulta managementu a ekonomiky, Mostní 5139, 76001 Zlín \\ Email:sfialova@fame.utb.cz
}

\begin{abstract}
In this article the current situation of the utilisation of costing in hospitals in the Czech Republic is dealt. The theoretical basis is described in the first section of the article which are followed by additional research results. In the research, the emphasis was on the composition of costs in hospitals, as well as the range of calculations and methods of calculation. In conclusion, the research results are evaluated and made recommendations. The research was performed as a part of the project of the Internal Grant Agency at the Tomas Bata University in Zlín on the subject theme“ Project of Analysing of Economic-Managerial Methods and Tools Utilised in the Hospitals in the Czech Republic" (IGA/FaME/2012004).
\end{abstract}

Keywords: $\mathrm{ABC}$ method, costing, hospital, job-order costing method, modern costing methods.

JEL classification: M10, M21

Doručeno redakci: 30.12.2012; Recenzováno: 4.3.2013; 24.2.2013; Schváleno k publikování: 11.9.2013

\section{Introduction}

Health care as a part of the tertiary sector is very expensive. Approximately $7.5 \%$ of the GDP is currently spent on the health care services by health insurance companies, the central government, regional governments and citizens themselves. In 2010, total expenditures on health care reached CZK 284.1 billion. Health care costs are currently growing faster than the real economy. The most expensive part of health care is represented by hospital care, which represents approximately the half of all expenditures. (OECD, 2012)

Currently, a conflict between reduction of costs in the health care services and improving their quality is on the increase. This conflict is dealt with not only by managers of hospitals and health insurance companies, but also by patients themselves. As a result of the conflict, the interest in development of cost accounting and in the better and detailed insight into the costs of health care services is developed. Hospitals, health care providers, health insurance companies as well as payers of the health care services want to know the actual level of costs of these services. The cost structure is currently modifying, both in production companies and services. Fixed costs are coming to the forefront, implying a new question of their appropriate and accurate allocation to each individual service. The aim of the research was to determine the cost structure, the level of costs of supportive services in hospitals, as well as cost allocation methods currently utilised in the Czech hospitals.

\section{Theoretical basic}

\section{Costs and costing in hospitals}

Costing in its most general sense is meant as allocation of costs, margins, profits, prices or other values to a unit of output expressed in the terms of volume (e.g. a product, a service, etc.) (Fibírová, 2011). In health care, costing is understood as a tool based on the principle of allocation and used to determine the price of health care services. Costing is performed by both health care services providers and health insurance companies. The results of these calculations are then utilised as the basis in the bargaining procedure between these two parties. Due to the fact that this procedure results in determination of the health care services 
prices, costing needs to be accurate and grounded on the thorough cost analysis. (Gladkij, 2003)

\section{Costing methods utilised in health organisations}

The costing method is understood as a procedure determining the level of costs per certain final product or medical procedure. Nowadays, there is a great range of costing methods which are utilised in hospitals both in the Czech Republic and other countries and are described thereinafter. According to Finkler (2007), one of the two following costing methods is predominantly utilised by the organisations: Job-Order Costing or Process Costing. Furthermore, new hybrid costing systems are being developed as well.

\section{Job-Order Costing}

This method represents calculation of full costs. Due to the fact that cost demands of various medical procedures differ, it is useful to monitor expenditures of each procedure separately and to create the calculation list of each order. All expenditures associated to the cure of the patient are recorded in this list. The problem in the cost quantification arises when indirect costs (e.g. the administrative staff salary) need to be allocated to one patient. (Finkler, 2007, Nowicki, 2008)

\section{Process Costing}

Using this method, costs per product within a reporting period are determined. The total costs of an organisation, a department, etc. are mostly divided among the number of products and services performed in a given period. This costing method can be utilised only if the same or similar services are provided over the entire period. (Finkler, 2007, Nowicki, 2008)

The Standard Costing method is classified as a hybrid costing method. A preliminary level of costs per unit, e.g. one product, is determined by this method. In case of health care facilities, the standard costs can be represented by expected costs per one specific patient. The standards are determined using historical results, observations over time or by theoretical calculation. Organisations using the standard costing method may have created a list of expenditures per their products. The product can be represented by a patient, a laboratory test or surgery. (Finkler, 2007, Toso, 2012)

The estimations of the cost levels for various types of patients are provided by the Standard costing method. Although it is found to be relatively accurate, the Microcosting method is even more exact (Finkler, 2007). This costing method is utilised in the health care sector. Using the procedure, the detailed summary of all items related to the care for the patient, including the quantification of these items costs, is created. All direct and indirect (overheads) costs associated with the patient's stay in the hospital over the whole duration of his stay are allocated by this method. Such items as a nurse's wage, lighting in the patient's ward, surgery or alimentation expenditures etc. are included in the costs. The main advantage of the method is a high level of accuracy with respect to local services or the patient's individual needs. Moreover, valuation of the new technology is enabled by this method as well. On the other hand, this method is relatively complicated and, therefore, not used extensively at the moment. (Kinsella, 2008, Clement, 2009)

\section{Activity Based Costing}

Activity Based Costing (ABC) is a method of allocating costs to products or services based on resources they consume. It is increasingly used all over the world. According to Popesko (2009), it is a method of assigning costs to objects where actual physical outputs of individual 
activities are being measured. This method, according to The Economist, aims to "change the way the costs are calculated". (The Economist, 1998, Rajabi, 2012)

ABC strives to reveal the actual cause of the origin of the costs leading to the specific use of common resources associated to the given activity. The method provides a range of information about costs, activities, medical procedures and cost objects. (Popesko, 2009)

ABC application consists of the following steps:

- The definition of activities is the first step when applying ABC. The activity itself is represented by a homogeneous set of operations that lead to the particular objective.

- In the second step, the identified indirect costs are assigned to particular activities defined in the step 1. The output of this activity is quantification of the total costs of individual activities (cost pool).

- $\quad$ The third step of the cost allocation within $\mathrm{ABC}$ is represented by the calculation of the unit costs of activities. It is composed of several consecutive steps. At first, the relational variable of activities (activity-cost driver) has to be determined for each defined activity. In general, this relational variable of activities represents the certain measure by which the output of the given activity can be measured. In the next phase it is necessary to determine the output of the given activity through the monitored period (output measure).

- In the third phase of the cost allocation within the ABC system, cost calculation of the chosen cost object is performed. The objective of this phase is to assign costs of activities to individual calculated cost objects. (Popesko, 2012)

The traditional method of costs allocation is called the "top-down" method because it begins with all expenditures which are further allocated downwards to various services. On the contrary, the ABC method is the "bottom-up" method because all expenditures of each service at the lowest level are firstly searched for. These are further allocated to individual services according to activities and processes. This procedure is depicted in the following figure. (Zelman, 2009)

Figure 1: Activity Based Costing

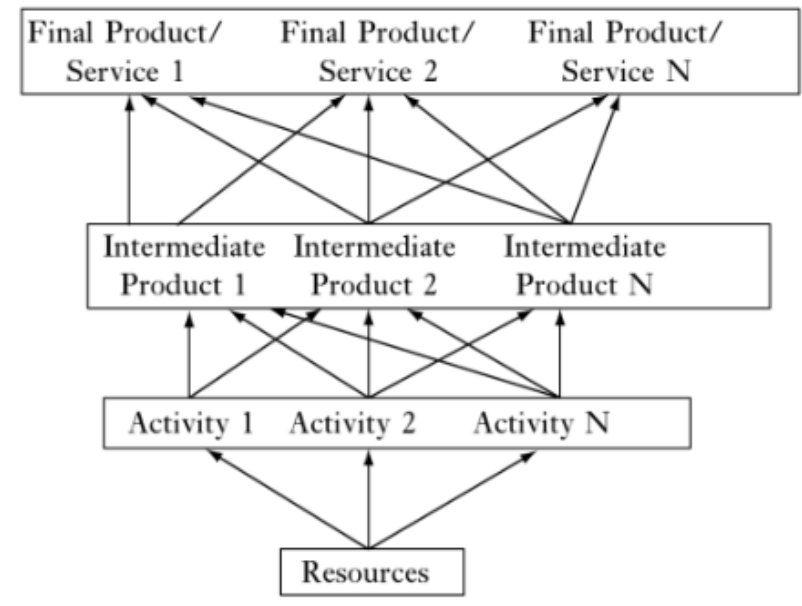

Source: Zelman, 2009 
Advantages of the ABC method:

- $\quad$ the resources spent on the cure are more accurate and better defined

- the resources consumed by the cost of the object are directly monitored and identified

- $\quad$ process management in hospitals is improved

Disadvantages of the ABC method:

- the method is relatively new and not well-known

- $\quad$ the hospital management may not necessarily wish to know the detailed level of costs (Baker, 1998, Carey, 2000)

Due to the fact that the vast majority of costs in health care is recorded in accounting as indirect costs to the given product (patient), approximation of costs to products is necessary when applying the ABC method. (National Reference Centre, 2009)

\section{The research objective, methodology and hypotheses}

\section{The research objective}

The following objectives of the research were defined:

1. To determine the cost structure in hospitals

2. To determine extent of costing utilisation in hospitals

3. To determine the prevailing method of costing

4. To determine causes for non-utilisation of other costing methods

\section{The research methodology}

The research was conducted through a questionnaire survey among CFOs or their deputies in various hospitals in the Czech Republic.

Consisting of 32 questions, the questionnaire was formulated to cover more areas related to cost management in hospitals. The questions were focused on both general economic data and cost management or utilisation of outsourcing and budgeting in hospital management. The questions were formulated both open and closed. This questionnaire has been consulted with economists in hospitals. Pre-test questionnaire was conducted which has identified errors in the questionnaire, which was then removed.

The questionnaire was distributed primarily by e-mails, or the responsible persons of the given hospitals were contacted in person. The total number of filled questionnaires reached 22. The data were collected from August to September 2012.

\section{Respondents}

The target group for the survey was limited by the number of hospitals in the Czech Republic. Based on the data of the Institute of Health Information and Statistics of the Czech Republic (IHIS), there are currently 167 hospitals in the Czech Republic. The questionnaire was filled in by approximately $13 \%$ of them. $82 \%$ of the filled questionnaires were from hospitals in the category 0-499 beds in the hospital. On the contrary, no questionnaire was filled in by any hospital with more than 1,000 beds. The precise structure of hospitals is shown in the following chart. 
Figure 2: Size structure of hospitals according to the number of beds

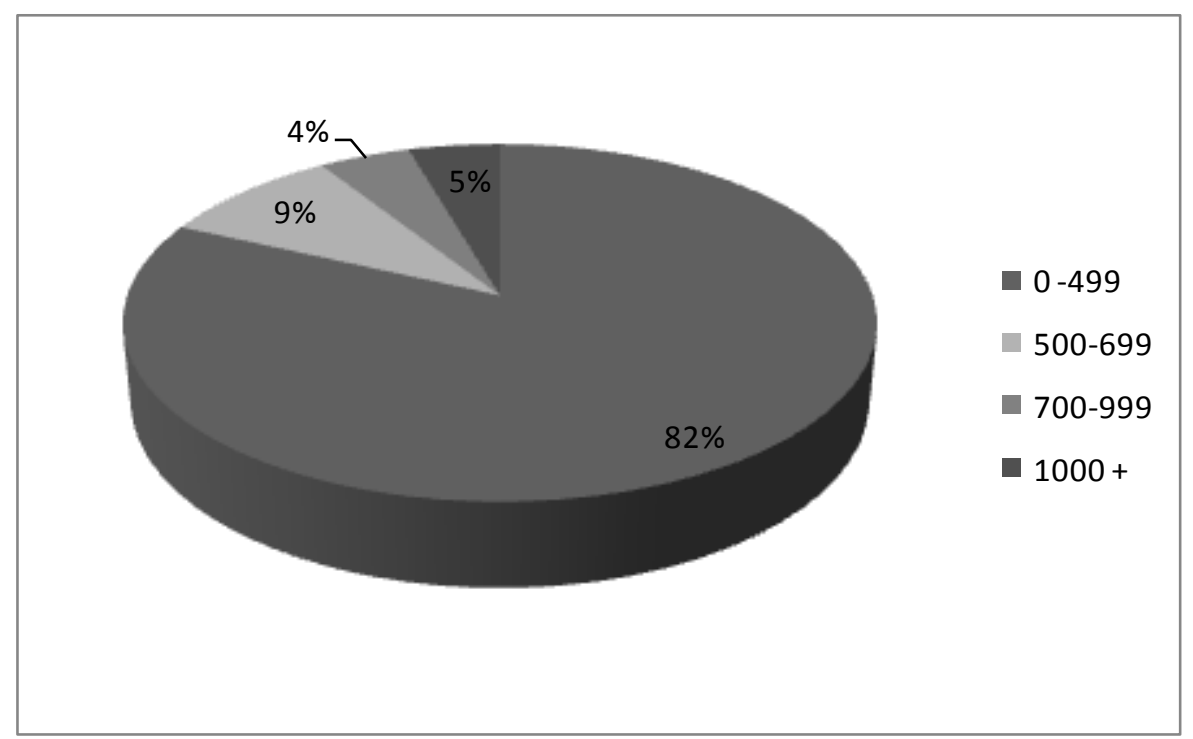

Source: own work

As for the structure of hospitals, university hospitals accounted for $18 \%$. Private hospitals accounted for only $9 \%$.

\section{The research hypotheses}

The following hypotheses were set within the research:

H1: Costing of medical procedures, both paid and unpaid from the health insurance, is performed by more than $50 \%$ of hospitals.

H2: Job-order costing is the most utilised method in the Czech hospitals.

H3: The hospital staff believes that the payment from the health insurance company does not correspond to the actual costs of medical procedure.

\section{The research results}

Based on experience and available data that are available from other areas of the economy, it was assumed that more than half of the costs will be indirect. This assumption is also fulfilled, an overview of costs and their structure are described below.

\section{The cost structure in hospitals}

As shown in the chart below, more than $55 \%$ of the total costs of hospitals are accounted for by personnel costs of employee; and it is not only the labour costs of doctors and nurses. The labour costs of the laboratory and other technicians as well as of operational and administrative staff are included as well. This percentage is relatively low in comparison to the Western Europe countries, where personnel costs fluctuate around 70\%. Another important item consists of medical devices, by which there is understood an instrument, appliances, tools, equipment, software, material or other objects that are used to diagnosing, prevention, monitoring, cure or alleviation of a disease. These devices account for approximately $12 \%$ of the total costs. Around $6 \%$ of the total costs are formed by medication costs. The "other costs" item includes e.g. costs of services, goods sold etc. Comparing the current level of costs to year 2000, the significant increase in salaries is apparent (by 
approximately $15 \%$ ) (IHIS ${ }^{1}$, hospitals, 2000). The slight decrease in the costs of amortisation, foodstuff, medications and energy is also evident, nevertheless, all only in order of a few percent.

Figure 3: Cost structure in hospitals (the data processing by the researchers)

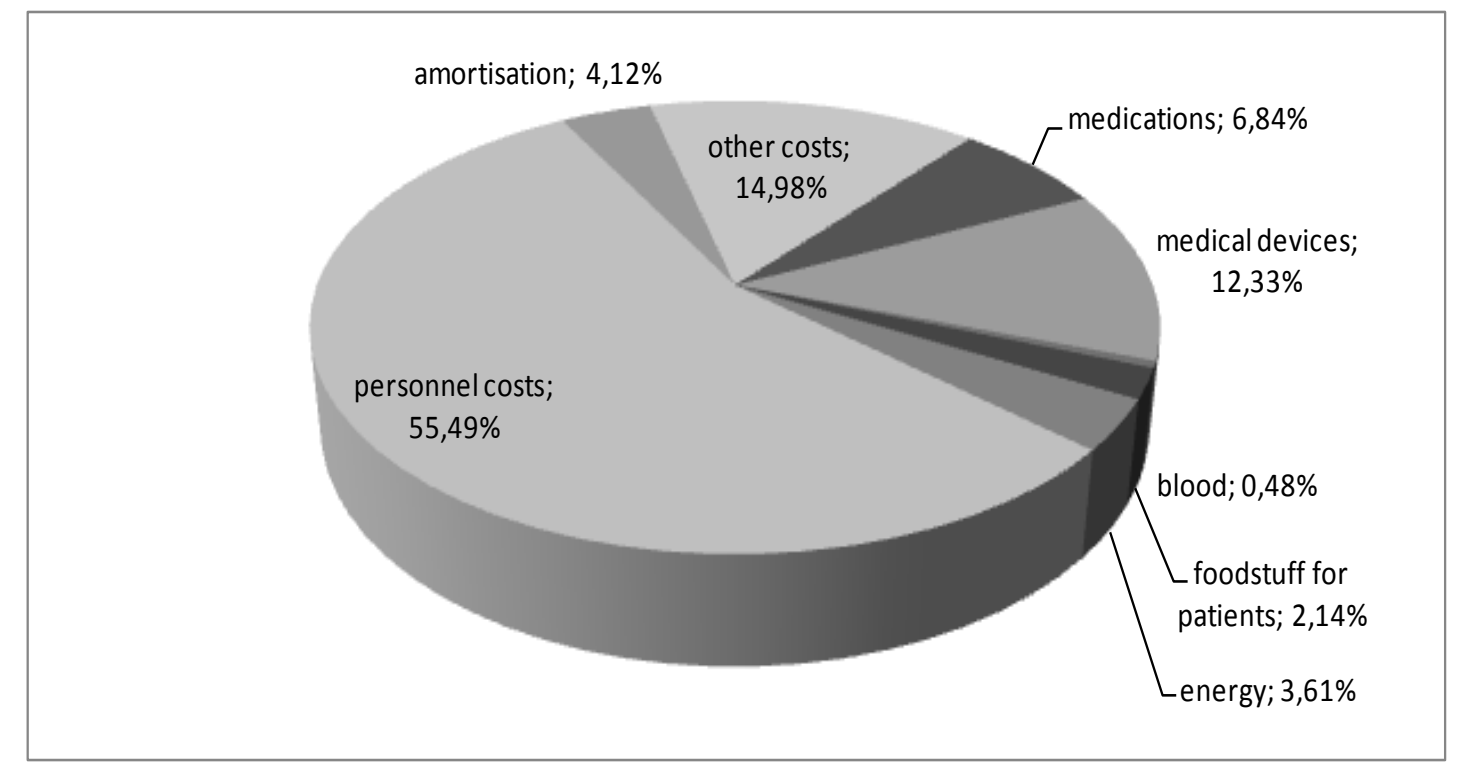

Source: own work

Approximately $11.5 \%$ of the total costs in hospitals are formed by costs of supportive activities such as administration, IT, human resources, laundry, catering section, etc.

\section{Costing of health care services}

Health care services may be classified into two groups - medical procedures paid by patients and medical procedures paid from public health insurance. If comparing these two groups of procedures and utilisation of costing for determination of their actual costs, it is found out that costing of procedures paid by patients is utilised by the majority of hospitals (approximately $82 \%$ ). On the other hand, the exact costs of procedures covered by public health insurance are calculated only by less than half of hospitals (approximately 45\%). This situation is depicted in the chart below.

\footnotetext{
${ }^{1}$ Institute of Health Information and Statistics of the Czech Republic was established in 1960. The Institute carries out collection and processing of health information management and national health registers.
} 
Figure 4: Costing of procedures covered and uncovered by public health insurance

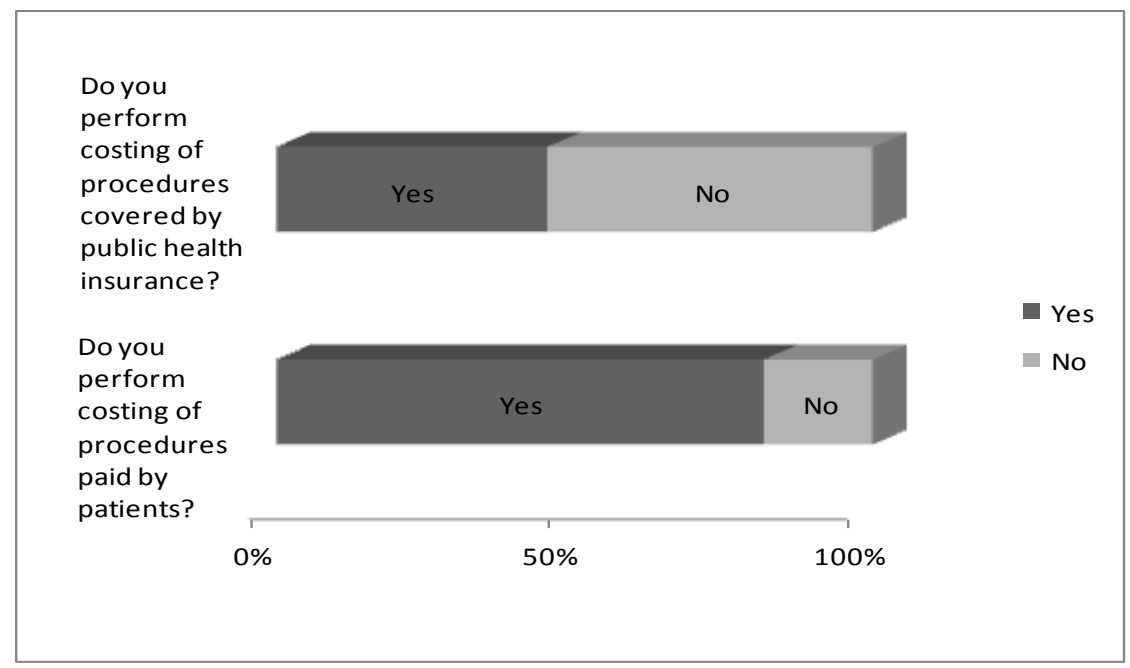

Source: own work

With regard to the costing methods applied in hospitals, the job-order costing method is used for the exact determination of the costs level in the majority of hospitals (almost 70\%). The variable costs calculation method and the ABC method are used as well. Although one of the simplest costing methods is used in hospitals, economists are convinced that this method reflects the actual level of costs. Approximately $77 \%$ of the hospital CFOs or their deputies are convinced of this fact. The summary of the applied costing methods is depicted in the following chart.

Figure 5: The costing methods utilised in the Czech hospitals

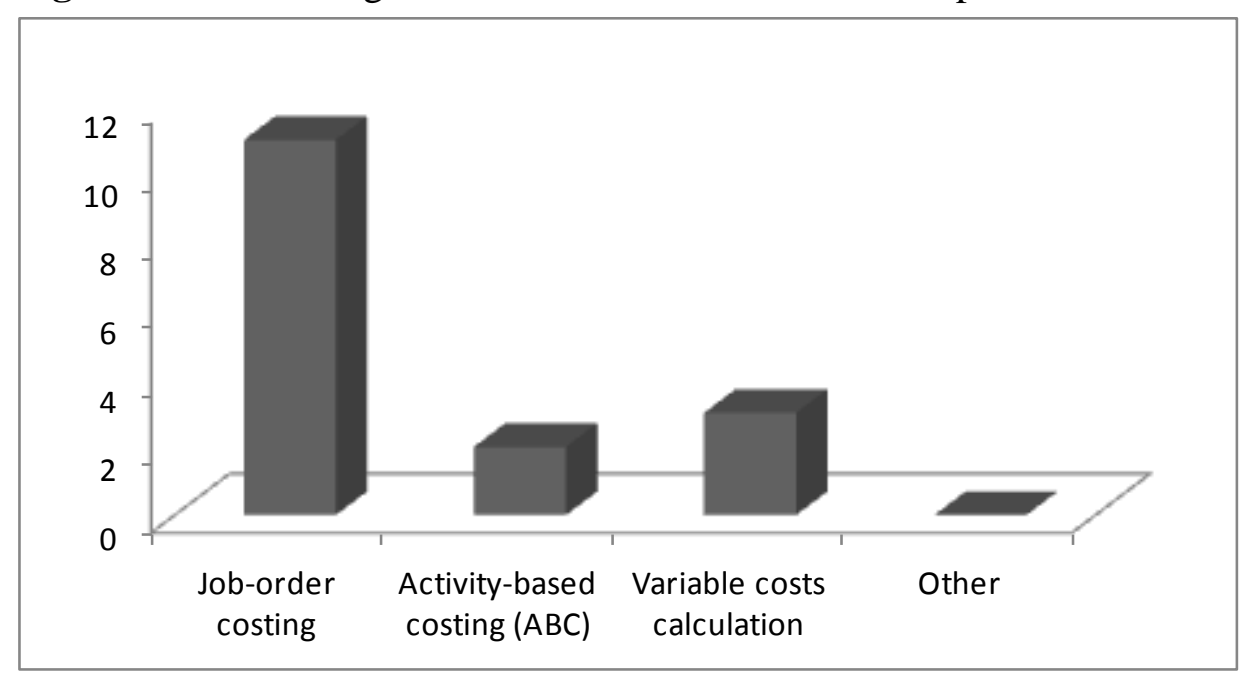

Source: own work

Although the majority of hospitals are convinced that the costing method they use displays objectively the actual level of costs per particular health service, they are not completely convinced of the match between the amount reimbursed by the health insurance company and the actual level of costs per medical procedure. As many as $90 \%$ of hospitals believe that the reimbursed amount does not correspond to the actual costs spent on a given medical procedure. Only $10 \%$ think that the reimbursed amount is in accordance with real expenses. 
Figure 6: Does the amount reimbursed by the health insurance company correspond to the actual costs of medical procedure?

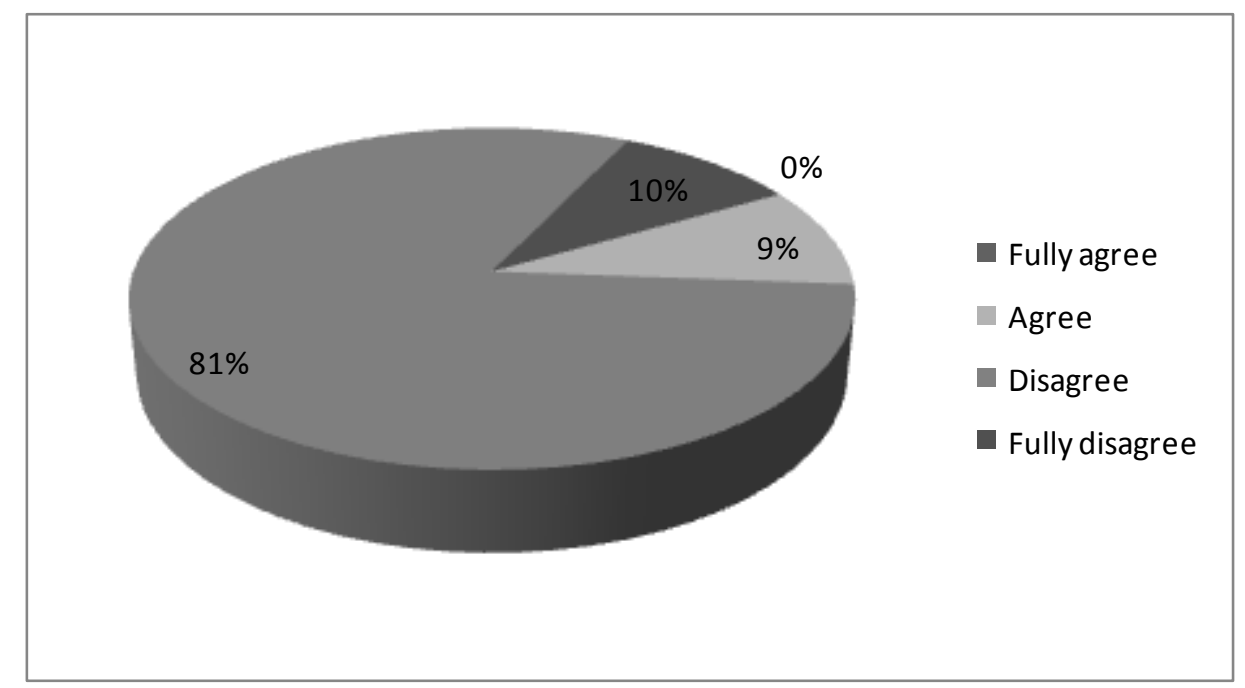

Source: own work

\section{The hypotheses verification}

At the end of the research, the verification of the hypotheses was performed.

H1: Costing of medical procedures, both paid and unpaid from the health insurance, is performed by more than $50 \%$ of the hospitals.

The first hypothesis was rejected because costing of medical procedures paid from the public health insurance is performed only by $45 \%$ of the hospitals.

H2: Job-order costing is the most applied method in the Czech hospitals.

In conditions of the Czech hospitals, the mostly applied costing method is the job-order costing method. Therefore, the second hypothesis was accepted.

H3: The hospital staff believes that payment from the health insurance company does not correspond to the actual costs of medical procedure.

As many as $90 \%$ of the hospitals believe that the reimbursed amount does not correspond to the actual costs spent on a given medical procedure. Therefore, the third hypothesis was accepted.

\section{Discussion}

The results provided by the questionnaire bring evidence concerning the Czech hospitals and their costs and driving. Despite the lower return the questionnaire, it is expected that the results are relevant. Data were compared with studies carried out in other similar countries. Results we first provide an overview of the cost structure, as well as the calculation and access to individual hospitals calculations. It is well known that health care costs are rising and it is therefore necessary to consider how the structure of these costs. We should also address the question of the correct and accurate allocation of costs to individual cost objects i.e. costing method. Thanks carried out the research were outlined answers to those questions. 


\section{Conclusion}

The Czech health care delivery and its associated costs have recently been a very frequent theme of discussions. It is well-known that the health care costs are rising continuously. However, is this trend sustainable in the long term? At first, it is necessary to know the exact level of costs caused by the given cost object. Based on this information, the price, which is subsequently either paid by patients themselves, or which becomes the object of the bargaining procedure between the health care facility and the health insurance company, is possible to be determined. Nowadays, costing of all medical procedures is performed only by less than half of the hospitals. The Job-Order costing method is applied in most cases. This costing method is one of the least difficult. The allocation base expressed in terms of volume or value is used to allocate common indirect costs to the procedures. This way of calculation, compared to e.g. the $\mathrm{ABC}$ method, is less accurate and does not result in actual outcomes. Therefore, it is necessary to focus on newer and more precise costing methods which are able to assign indirect costs to the cost object more accurately. The cost object is supposed to be medical procedures such as the surgical procedure, examination, etc. Until the exact costs of medical procedures remain unknown, it will not be possible to seek efficient cost-cutting solutions which would not have the negative impact on the quality of the provided health care.

\section{Acknowledgement}

This paper is one of the research outputs of project the Internal Grant Agency of FaME TBU No. IGA/FaME/2012004 - „Project of Analysing of Economic-Managerial Methods and Tools Utilised in the Hospitals in the Czech Republic".

\section{References}

[1] BAKER, J. J., 1998. Activity-based costing and activity-based management for health care. Gaithersburg, Md.: Aspen, pp. 385, ISBN 0-8342-1115-7.

[2] CAREY, K. and J. F. BURGESS, 2000. Hospital Costing : Experience form the VHA. Financial Accountability\&Management.. Vol. 16, Issue 4, pp. 289-308.

[3] CLEMENT, F., W. A. GHALI, C. DONALDSON and M. J. BRADEN, 2009. The Impact of Using Different Costing Method on the Results of an Economic Evaluation of Cardiac Care: Microcosting Vs. Gross-Costing Approaches. Health Economics 18, , pp. 377-388.

[4] FIBÍROVÁ, J., L. ŠOLJAKOVÁ a J. WAGNER, 2011. Manažerské účetnictví: nástroje a metody., 1st ed. Praha: Wolters Kluwer Česká republika, pp. 391. ISBN 978-80-7357712-4.

[5] FINKLER, S. A, D. M. WARD and J. J. BAKER. Essentials of cost accounting for health care organizations. 2007, 3rd ed. Sudbury: Jones and Bartlett Publishers, pp. 484, ISBN 0-7637-3813-1.

[6] GLADKIJ, I., 2003. Management ve zdravotnictví., 1st ed. Brno: Computer Press, pp. 380, ISBN 80-7226-996-8.

[7] KINSELLA, S., 2008. Ten Lessons for Micro Costing in Health Economics [online]. [cit. 7.8.2012]. Available from: http://www.stephenkinsella.net/2008/07/04/985/.

[8] National Reference Centre.cz: DRG pro laiky [online], 2008. Praha: NRC, [cit. 7.8.2012]. Available from: http://www.nrc.cz/cinnosti/drg/co-je-drg/drg-pro-laiky. 
[9] NOWICKI, M., 2008. The financial management of hospitals and health care organizations. 4th ed., Chicago, IL: Health Administration Press, pp. 386, ISBN 978-156793-277-5.

[10] OECD: OECD Health Data 2012 - Frequently Requested Data [online]. Paris: 2012 [cit. 7.8.2012]. Available

from: http://www.oecd.org/els/healthpoliciesanddata/oecdhealthdata2012frequentlyrequesteddata.htm.

[11] POPESKO, B., 2009. Moderní metody ř́zení nákladi̊: jak dosáhnout efektivního vynakládání nákladi̊ a jejich snižení., 1st ed. Praha: Grada, pp. 233, ISBN 978-80-2472974-9.

[12] POPESKO, B., 2012. Businessinfo:Procesní ř́zení nákladio s využitím metody aktivity based costing [online]. Praha: Businessinfo,[cit. 7.8.2012]. Available from: http://www.businessinfo.cz/cs/clanky/procesni-rizeni-nakladu-s-vyuzitim-metodyactivity-based-costing-19730.html.

[13] RAJABI, A. and A. Dabiri, 2012. Applying Activity Based Costing (ABC) Method to Calculate Cost Price in Hospital and Remedy Services. Iranian J Publ Health. Vol. 41, No.4, pp. 100-107.

[14] The Economist.com: Cost-cutting activity [online], 1998. Zurich: The Economist,[cit. 7.8.2012]. Available from: http://www.economist.com/node/170157.

[15] TOSO, M. E. Cost Accounting and Cost Accounting Systems in Health Care Organizations.[cit.7.8.2012]. Available from: http://www.trinethealth.com/Articles/Cost\%20Acctg\%20\&\%20Cost $\% 20$ Acctg\%20Syste ms\%20in\%20Health care\%20Org.pdf.

[16] ZELMAN, W. N., M. J. MCCUE and N. D. GLICK., 2009. Financial management of health care organizations: an introduction to fundamental tools, concepts, and applications. 3rd ed. San Francisco, CA:Jossey-Bass, pp. 600, ISBN 978-0-470-49752-4. 